\title{
PENINGKATAN KUALITAS PEMBELAJARAN MENYIMAK \\ CERPEN DENGAN MENGGUNAKAN MEDIA REKAMAN \\ PEMBACAAN CERPEN PADA SISWA KELAS XI IPA2 SMA NEGERI 1 BONTOTIRO KABUPATEN BULUKUMBA
}

\author{
ANDI NURFAIZAH \\ FTIK UIN DATOKARAMA PALU \\ andinurfaizah89@gmail.com
}

Abstract

This study aims to describe the improvement in the quality of learning to listen to short stories using short story reading recording media for students of class XI IPA2 SMA Negeri 1 Bontotiro, Bulukumba Regency. The results of the study prove that improving the quality of learning to listen to short stories using short story reading recording media in class XI IPA2 SMA Negeri 1 Bontotiro Bulukumba Regency at the planning stage found an increase in the ability of teachers in the field of study to plan better learning implementation in cycle II. In the implementation stage, there was an increase in student activity during the learning process, such as the sincerity, discipline, and self-confidence of students following the learning process. The evaluation stage found an increase in the results of the short story listening test, showing that in the first cycle 56.09\% of students experienced mastery learning, and in the second cycle it reached $97.56 \%$ who experienced learning mastery. Based on the results of the study, it was concluded that the recording media for reading short stories could improve the quality of learning to listen to short stories in class XI IPA2 SMA Negeri 1 Bontotiro, Bulukumba Regency.

Keywords: Short Story Reading Recording Media, Learning, Listening, Short Story

Abstrak

Penelitian ini bertujuan mendeskripsikan peningkatan kualitas pembelajaran menyimak cerpen dengan menggunakan media rekaman pembacaan cerpen pada siswa kelas XI IPA2 SMA Negeri 1 Bontotiro Kabupaten Bulukumba. Hasil penelitian membuktikan bahwa Peningkatan kualitas pembelajaran menyimak Cerpen dengan menggunakan media rekaman pembacaan cerpen pada siswa kelas XI IPA2 SMA Negeri 1 Bontotiro Kabupaten Bulukumba pada tahap perencanaan ditemukan peningkatan kemampuan guru bidang studi dalam merencanakan pelaksanaan pembelajaran yang lebih baik pada siklus II. Tahap pelaksanaan terjadi peningkatan keaktifan siswa selama proses pembelajaran, seperti pada kesungguhan, kedisiplinan, dan rasa percaya diri siswa mengikuti proses pembelajaran. Tahap evaluasi ditemukan peningkatan hasil tes menyimak cerpen, menunjukkan bahwa pada siklus I 56,09\% siswa yang mengalami ketuntasan belajar, dan pada siklus II mencapai $97,56 \%$ yang mengalami ketuntasan belajar. 
Berdasarkan hasil penelitian disimpulkan bahwa media rekaman pembacaan cerpen dapat meningkatkan kualitas pembelajaran menyimak cerpen pada siswa kelas XI IPA2 SMA Negeri 1 Bontotiro Kabupaten Bulukumba.

Kata Kunci: Media Rekaman Pembacaan Cerpen, Pembelajaran, Menyimak, Cerpen

\section{PENDAHULUAN}

Pada tahun pelajaran 2006/2007, Depdiknas meluncurkan Kurikulum Tingkat Satuan Pendidikan (KTSP). KTSP memberi keleluasaan penuh setiap sekolah mengembangkan kurikulum dengan tetap memperhatikan potensi sekolah dan potensi daerah sekitar. Keuntungan yang bisa diraih guru dengan KTSP ini adalah keleluasaan penuh dalam memilih bahan ajar dan peserta didik diharapkan dapat mengembangkan potensinya sesuai dengan kemampuan, kebutuhan dan minatnya. Dalam KTSP standar kompetensi pembelajaran bahasa Indonesia meliputi empat sub aspek yakni menyimak, berbicara, membaca, dan menulis. Keempat aspek keterampilan tersebut bertujuan dalam menyampaikan pikiran, gagasan, dan pendapat, baik secara lisan maupun tertulis, sesuai dengan konteks komunikasi yang harus dikuasai oleh pemakai bahasa, dengan keempat aspek kemampuan berbahasa tersebut, diharapkan tujuan umum pembelajaran bahasa Indonesia dapat tercapai.

Mata pelajaran bahasa Indonesia diharapkan dapat mengembangkan potensi peserta didik sesuai dengan kemampuan, kebutuhan, dan minatnya serta dapat menumbuhkan penghargaan terhadap hasil karya kesastraan dan hasil intelektual bangsa sendiri. Pembelajaran bahasa Indonesia diarahkan untuk meningkatkan kemampuan peserta didik dalam berkomunikasi dengan menggunakan bahasa Indonesia yang baik dan benar, baik secara lisan maupun tulisan.

Penerapan mata pelajaran bahasa Indonesia berisi pengetahuan serta keterampilan bersastra. Pengetahuan kesastraan meliputi pengetahuan prosa fiksi, puisi, dan drama. Pembelajaran sastra Indonesia meliputi empat aspek keterampilan. Menurut Tarigan, keterampilan berbahasa keempat komponen tersebut terdiri atas: 1) keterampilan menyimak (listening skills); 2) keterampilan berbicara (speaking skills); 3) keterampilan membaca (reading skills); dan 4) keterampilan menulis (writing skills). ${ }^{1}$ Aspek keterampilan tersebut bertujuan dalam menyampaikan pikiran,

\footnotetext{
${ }^{1}$ H. G. Tarigan, Berbicara Sebagai Suatu Keterampilan Berbahasa, (Bandung: Angkasa, 2013), 1.
} 
gagasan, dan pendapat, baik secara lisan maupun tertulis, sesuai dengan konteks komunikasi yang harus dikuasai oleh pemakai bahasa, diharapkan tujuan umum pembelajaran bahasa dan sastra Indonesia dapat tercapai.

Pembelajaran sastra di sekolah menumbuhkan kesadaran siswa akan pentingnya mengapresiasi sastra yang dapat dilakukan dengan kegiatan, yaitu 1. interpretasi (penafsiran) adalah upaya memahami karya sastra dengan memberikan tafsiran berdasarkan sifat-sifat karya sastra itu sendiri; 2. analisis adalah penguraian karya sastra atas bagian-bagian atau norma-norma secara lebih khusus; 3. evaluasi (penilaian) adalah usaha menentukan kadar keberhasilan atau keindahan suatu karya sastra, serta dengan membaca karya sastra siswa dapat mengungkapkan ide dan gagasannya.

Penerapan mata pelajaran bahasa Indonesia berisi pengetahuan serta keterampilan bersastra. Pengetahuan kesastraan meliputi pengetahuan prosa fiksi, puisi, dan drama. Sedangkan keterampilan bersastra meliputi keterampilan menyimak, berbicara, membaca, dan menulis. Menurut Oemarjati, "Pengajaran sastra pada dasarnya mengemban misi efektif, yaitu memperkaya pengalaman siswa dan menjadikannya lebih tanggap terhadap peristiwaperistiwa di sekelilingnya. Tujuan akhirnya adalah menanam, menumbuhkan, dan mengembangkan kepekaan terhadap masalah-masalah manusiawi, pengenalan dan rasa hormatnya terhadap tata nilai, baik dalam konteks individual, maupun sosial."

Salah satu bentuk karya sastra adalah cerpen. Cerpen adalah cerita narasi yang selesai dibaca dalam satu kali duduk. Cerpen merupakan salah satu materi pembelajaran sastra yang diajarkan di sekolah berdasarkan KTSP tingkat SMA dan harus dikuasai siswa. Tercantum dalam standar kompetensi yakni memahami pembacaan cerpen dan kompetensi dasar yakni mengidentifikasi alur, penokohan, dan latar dalam cerpen yang dibacakan, serta menemukan nilai-nilai dalam cerpen yang dibacakan pada kelas XI semester II dengan sub aspek menyimak. Dalam proses pelaksanaan pembelajaran menyimak cerpen, masih banyak siswa yang tidak bisa memahami dengan baik cerpen yang disimak bahkan ada yang tidak aktif dan merasa bosan selama proses pembelajaran menyimak hal ini disebabkan karena guru tidak memakai media pembelajaran yang variatif, maksudnya media yang biasa digunakan oleh guru hanya berupa papan tulis dan ispidol. Permasalahan yang sama terjadi di Kelas XI IPA2 SMA Negeri 1 Bontotiro Kabupaten Bulukumba. Saat peneliti melakukan

${ }^{2}$ Boen S. Oemarjati, Dengan Sastra Mencerdaskan Siswa: Memperkaya Pengalaman dan Pengetahuan, (Jakarta: Pustaka Sinar Harapan,1992). 
kegiatan observasi awal, peneliti memperoleh gambaran yang jelas mengenai pelaksanaan pembelajaran Bahasa Indonesia di sekolah tersebut. Adapun hasil kegiatan observasi awal peneliti adalah: 1). Media yang diterapkan guru dalam pembelajaran menyimak tidak variatif, maksudnya media yang diterapkan guru hanya berupa ispidol dan papan tulis, hal ini disebabkan karena keterbatasan media pembelajaran di sekolah tersebut. Oleh karena itu, guru hanya membacakan cerpen yang akan disimak sehingga berakibat ada beberapa siswa kurang mendengar yang dibacakan oleh guru. Biasanya guru hanya menyuruh siswa untuk membacakan cerpen yang akan disimak dan hal ini berarti bukan lagi merupakan aspek menyimak tetapi aspek membaca. 2). Sebagian besar siswa tidak aktif bahkan ada yang tidak memperhatikan saat pembelajaran menyimak cerpen berlangsung sehingga sebagian besar siswa kesulitan dalam menentukan unsur-unsur intrinsik cerpen. 3). Guru mengalami kesulitan dalam menghadirkan media yang tepat dalam pembelajaran menyimak cerpen.

Oleh karena itu, sangat diperlukan adanya pembaharuan media, strategi, teknik, metode pembelajaran, maupun pendekatan yang digunakan oleh guru yang dapat membangkitkan semangat, kreatifitas, dan aktivitas siswa selama proses pembelajaran.

Sudjana dan Rivai mengatakan bahwa media pembelajaran dapat meningkatkan hasil belajar siswa, yaitu: Mengajar akan menarik perhatian siswa sehingga dapat menumbuhkan motivasi belajar dan makna materi pelajaran akan lebih jelas sehingga dapat lebih dipahami oleh siswa siswa, dan memungkinkan siswa untuk lebih menguasai tujuan pembelajaran. ${ }^{3}$ Salah satu media pembelajaran yang melibatkan para peserta didik secara aktif dalam memperoleh dan memahami pembelajaran menyimak cerpen yakni media rekaman pembacaan cerpen yang berupa media audio. Media audio merupakan media yang menggunakan indera pendengaran dan dapat membangkitkan motivasi siswa dalam proses pembelajaran.

Penelitian yang relevan dilakukan oleh A. Suriani berupa penelitian eksperimen dengan judul penelitian "Penggunaan Tape Recorder Dalam Pembelajaran Menyimak Siswa Kelas X Man 1 Makassar". Hasil penelitiannya menunjukkan bahwa pengguanaan media pembelajaran tape recorder efektif dalam pembelajaran menyimak. ${ }^{4}$ 2013), 2.

${ }^{3}$ Sudjana \& Ahmad Rivai, Media Pengajaran, (Bandung: Sinar Baru Algensindo,

${ }^{4}$ A. Suriani, Penggunaan tape Recorder Dalam Pembelajaran Menyimak Siswa Kelas X MAN 1 Makassar. (Skripsi. Makassar: FBS UNM, 2005). 
Selanjutnya, penelitian yang sama juga dilakukan oleh Andi Dewi Astuti berupa penelitian eksperimen dengan judul penelitian "Penggunaan Laborotorium Bahasa Dalam Pembelajaran Menyimak Cerpen Siswa Kelas X SMA Negeri 3 Sengkang". Hasil penelitiannya menunjukkan bahwa penggunaan media laborotorium bahasa efektif dalam pembelajaran menyimak cerpen. ${ }^{5}$

Penelitian Tindakan Kelas (PTK) yang dipilih sebagai alat dalam menangani permasalahan mengidentifikasi unsur-unsur intrinsik cerpen dilakukan oleh Fitriani. Fitriani menggunakan media rekaman pembacaan cerpen, hasil penelitian menunjukkan mampu memberikan peningkatan dalam mengidentifikasi unsur-unsur intrinsik cerpen. ${ }^{6}$

Berdasarkan uraian hasil penelitian terdahulu di atas, dapat disimpulkan penggunaan media pembelajaran efektif digunakan dalam proses pembelajaran. Oleh karena itu peneliti tertarik untuk melakukan penelitian tindakan kelas dengan judul penelitian "Peningkatan Kualitas Pembelajaran Menyimak Cerpen dengan Menggunakan Media Rekaman Pembacaan Cerpen pada Siswa Kelas XI IPA2 SMA Negeri 1 Bontotiro Kabupaten Bulukumba. Artikel penelitian ini bertujuan untuk mengkaji peningkatan kualitas pembelajaran menyimak cerpen dengan menggunakan media rekaman pembacaan cerpen pada siswa kelas XI IPA2 SMA Negeri 1 Bontotiro Kabupaten Bulukumba pada tahap perencanaan, pelaksanaan, dan evaluasi.

Artikel ini membahas tentang peningkatan kualitas pembelajaran menyimak cerpen dengan menggunakan media rekaman pembacaan cerpen pada Siswa Kelas XI IPA2 SMA Negeri 1 Bontotiro Kabupaten Bulukumba. Fokus pembahasan peningkatan kualitas pembelajaran menyimak cerpen dengan menggunakan media rekaman pembacaan cerpen. Jenis penelitian ini adalah Penelitian Tindakan Kelas, data dalam penelitian ini berupa data perencanaan, pelaksanaan, dan evaluasi. Adapun teknik pengumpulan data, melalui empat tahapan yakni peneliti berkolaborasi dengan guru melakukan perencanaan; kemudian peneliti melakukan pengamatan terhadap guru dan siswa; tahapan ketiga yakni peneliti melakukan evaluasi terhadap guru dan siswa, dan tahapan terakhir yakni merefleksi hasil penelitian. Penelitian ini dilaksanakan dalam 2 (dua) siklus dengan tahapan yang sama. Teknik analisis data dianalisis secara

${ }^{5}$ Andi Dewi Astuti, Penggunaan Laborotorium Bahasa dalam Pembelajaran Menyimak Cerpen Siswa Kelas X SMA negeri 3 Sengkang, (Skripsi. Makassar: FBS UNM, 2008).

${ }^{6}$ Fitriani, Peningkatan Kemampuan Mengidentifikasi Unsur-Unsur Intrinsik Cerpen Melalui Media Rekaman Pembacaan Cerpen Pada Siswa Kelas XI SMA negeri 1 Tompubulu Kabupaten Maros, (Skripsi. Makassar: FBS UNM, 2010). 
kualitatif dan kuantitatif. Untuk data proses dianalisis secara deskriptif kualitatif, sedangkan data hasil belajar dianalis secara deskriptif kuantitatif. Data kualitatif yaitu data berupa informasi berbentuk kalimat yang memberi gambaran tentang suasana kelas dan batin peserta didik (perhatian, antusias, percaya diri, dan motivasi dalam belajar) yang diperoleh melalui lembar observasi, dokumentasi, dan wawancara sedangkan data kuantitatif adalah tes yang mengambarkan prestasi akademik yang diperoleh dari hasil tes siswa.

Data yang diperoleh direduksi berdasarkan masalah yang diteliti, diikuti penyajian data, dan terakhir adalah penyimpulan dan verifikasi. Langkah analisis data dilakukan berulang-ulang. Tahap analisis data diuraikan sebagai berikut:1) Data yang terkumupul melalui observasi, dokumentasi, dan wawancara ditelaah dengan proses transkripsi hasil. Data dikelompokkan berdasarkan data pada tiap siklus; 2) Data keseluruhan yang terkumpul diseleksi dan diidentifikasi berdasarkan kelompoknya dan menghasilkan data sesuai kebutuhan; 3) Penyajian data dilakukan dengan cara mengorganisasikan informasi yang telah direduksi. Keseluruhan data dirangkum dan disajikan secara terpadu sesuai siklus yang direncanakan sehingga berfokus pada pembelajaran; 4) Akhir temuan penelitian disimpulkan dan dilakukan kegiatan triangulasi atau pengujian temuan penelitian. Keabsahan data diuji dengan memikirkan kembali hal-hal yang telah dilakukan dan dikemukakan melalui tukar pendapat dengan ahli atau pembimbing, teman sejawat, peninjauan kembali hasil observasi, wawancara, dokumentasi, serta triangulasi dengan teman sejawat atau guru setelah pelajaran.

\section{PEMBAHASAN}

\section{Siklus I}

Pada tahap perencanaan peneliti melakukan diskusi dengan guru mata pelajaran bahasa dan sastra Indonesia untuk membahas masalah atau kendala yang dialami oleh guru dan siswa dalam pembelajaran menyimak cerpen. Peneliti dan guru menyusun rencana pelaksanaan pembelajaran (RPP), waktu penelitian, media pembelajaran, dan penilaian akhir untuk membelajarkan siswa agar tujuan pembelajaran dapat tercapai secara maksimal. Peneliti juga menentukan pokok bahasan yang akan diajarkan dalam penelitian yaitu, cerpen dan unsur intrinsik cerpen yakni tema, tokoh dan penokohan, latar, alur, sudut pandang, gaya bahasa dan amanat. Selain itu, peneliti juga telah menyiapkan lembar observasi, lembar wawancara, dan alat dokumentasi, untuk menilai proses pembelajaran yang sedang berlangsung. Peneliti mengamati proses pembelajaran yang dilakukan oleh 
guru dan aktivitas siswa selama proses pembelajaran dengan menerapkan media rekaman pembacaan cerpen.

Pelakasanaan siklus I berlangsung selama tiga kali pertemuan (6x45 menit). Pertemuan pertama guru menjelaskan teori tentang cerpen dan unsur intrinsik cerpen yaitu tema, tokoh dan penokohan, dan latar. Pada pertemuan pertama ini kondisi kelas kurang kondusif, hal ini disebabkan karena banyak siswa yang bercerita dengan teman sebangkunya, melamun, bahkan mengantuk saat guru menjelaskan materi pembelajaran. Pada kegiatan pembelajaran menjawab pertanyaan apersepsi, hanya sedikit siswa yang bisa menjawab pertanyaan, siswa terlihat tampak ragu apabila ingin menjawab pertanyaan. Namun, pada saat siswa diperdengarkan rekaman pembacaan cerpen, kondisi kelas saat itu tampak hening sebagian besar siswa menyimak cerpen dengan sungguh-sungguh, tetapi ada juga siswa yang sesekali menyimak sambil bercerita dengan teman sebangkunya, bahkan ada yang tertawa apabila ada kutipan cerpen yang menurutnya lucu. Pada kegiatan pembelajaran diskusi kelas, hanya sebagian kecil siswa yang berani berbicara di depan teman-temannya, dan hanya siswa yang berperan aktif dari awal pembelajaran saja. Menurut peneliti kondisi kelas yang kurang kondusif pada pertemuan pertama ini disebabkan karena guru yang tidak pernah memberikan motivasi kepada siswa, selain itu kesulitan yang dihadapi oleh guru dalam memberikan sebuah contoh materi pembelajaran yang berhubungan dengan lingkungan sekitar, sehingga guru tidak maksimal dalam mengaitkan materi dengan realitas kehidupan dan menyebabkan banyak siswa yang tidak terlalu memahami materi pembelajaran.

Pada pertemuan kedua guru menjelaskan unsur intrinsik cerpen yaitu alur, sudut pandang, gaya bahasa, dan amanat. Pada pertemuan kedua ini siswa yang aktif bertambah. Sebagian besar siswa terlihat tenang dan antusias dalam menyimak materi pembelajaran. Pada kegiatan pembelajaran menjawab pertanyaan apersepsi, mengalami peningkatan dari pertemuan pertama, siswa yang bisa menjawab pertanyaan bertambah, namun tetap didominasi oleh siswa yang tidak bisa menjawab pertanyaan, siswa masih terlihat tampak ragu apabila ingin menjawab suatu pertanyaan, takut kalau jawaban yang akan dikemukakannya salah. Pada kegiatan pembelajaran siswa diperdengarkan rekaman pembacaan cerpen, sebagian besar siswa sangat antusias dalam menyimak, siswa yang aktif pada kegiatan pembelajaran ini bertambah karena seringnya guru memberikan arahan dan teguran kepada siswa yang sering bercerita, tetapi meskipun sering ditegur oleh guru apabila ada siswa yang luput dari perhatian guru, maka siswa tersebut mengambil kesempatan untuk bercerita sambil sesekali menyimak. Pada kegiatan pembelajaran diskusi kelas juga 
mengalami peningkatan dari pertemuan pertama, tetapi masih tetap didominasi oleh siswa yang tidak aktif. Ada beberapa siswa yang kurang aktif dalam kegiatan diskusi kelas pada pertemuan pertama, dan pada pertemuan kedua siswa tersebut sudah sangat aktif, sedangkan siswa yang tidak aktif pada pertemuan pertama, masih tetap tidak aktif pada pertemuan kedua. Menurut peneliti bertambahnya siswa yang aktif pada pertemuan kedua ini disebabkan karena guru yang telah memberikan motivasi kepada siswa pada awal pembelajaran dan pada akhir pembelajaran, tetapi belum terlaksana secara maksimal, karena guru hanya memusatkan perhatian kepada siswa tertentu saja tanpa berusaha mendekati siswa yang tidak aktif. Selain itu seringnya guru memberikan arahan dan teguran kepada siswa yang sering bercerita. Pada pertemuan yang kedua ini guru masih belum maksimal dalam mengaitkan materi dengan realitas kehidupan, hanya sebagian materi saja yang guru kaitkan dengan realitas kehidupan.

Pada pertemuan ketiga guru hanya memberikan pertanyaan apersepsi mengenai materi yang telah dijelaskan pada pertemuan pertama dan kedua, setelah itu siswa diperdengarkan rekaman pembacaan cerpen, kemudian setiap siswa dibagikan lembaran soal dan lembar jawaban, selanjutnya siswa mengerjakan tugas yang diberikan dengan mengidentifikasi unsur-unsur intrinsik cerpen yang berupa tes objektif pilihan ganda. Pada pertemuan ketiga ini siswa yang bisa menjawab pertanyaan bertambah dari pertemuan kedua, tetapi masih tetap didominasi oleh siswa yang tidak bisa menjawab pertanyaan apersepsi. Namun, pada saat siswa menyimak cerpen dan mengerjakan tugas dengan mengidentifikasi unsur-unsur intrinsik cerpen didominasi oleh siswa yang aktif. Hanya siswa tidak serius saja dalam menyimak cerpen, yang tidak terlalu memahami soal yang dikerjakan. Menurut peneliti pada pertemuan ketiga ini, yang menyebabkan masih banyaknya siswa yang tidak bisa menjawab pertanyaan karena pada pertemuan pertama dan kedua guru belum maksimal dalam mengaitkan materi dengan realitas kehidupan sehingga masih ada siswa tidak terlalu memahami materi pembelajaran dengan baik dan tidak bisa menjawab pertanyaan apersepsi. Dengan masih banyaknya siswa yang kurang antusias dan berperan aktif pada proses pembelajaran, dan guru yang belum maksimal dalam melaksanakan proses pembelajaran, sehingga berdampak pada hasil tes menyimak cerpen yang dicapai hanya $56,09 \%$ dari target $65 \%$.

Pada tahap evaluasi pembelajaran, hasil tes pembelajaran siklus I menunjukkan bahwa nilai rata-rata siswa siklus I adalah 65,48 dengan 23 siswa atau sebesar 56,09\% dari keseluruhan jumlah siswa yang memperoleh nilai $\geq 65$ artinya masih kurang dari target penelitian, yaitu siswa yang mendapat nilai hasil belajar 65 ke atas $\geq 65 \%$ sehingga 
penelitian perlu dilanjutkan ke siklus II dengan mempertahankan pencapaian pada siklus I.

\section{Siklus II}

Tahap perencanaan disiklus II, peneliti dan guru merumuskan rencana pelaksanaan pembelajaran baru sesuai hasil refleksi pada siklus I, di dalam rencana pelaksanaan pembelajaran diterapkan strategi baru yaitu, guru merancang materi pembelajaran dan menyajikan materi pembelajaran secara lebih jelas agar tujuan pembelajaran yang diharapkan dapat tercapai maka dilakukan dengan cara guru menjelaskan materi pembelajaran sambil menghubungkan dengan lingkungan sekitar, atau mengambil contoh dari kehidupan sekitar, hal ini dilakukan supaya siswa lebih paham terhadap materi yang dijelaskan, karena pada siklus I masih banyak siswa yang belum terlalu paham dengan materi yang dijelaskan, selain itu guru memandu pengajaran di kelas dengan menciptakan suasana di dalam kelas lebih kondusif supaya siswa dapat berperan aktif maka dilakukan dengan cara guru memberikan motivasi kepada siswa secara maksimal. Strategi yang diterapkan pada rencana pelaksanaan pembelajaran disiklus II seperti yang dipaparkan di atas, disebut dengan strategi model of teaching atau yang diartikan model pengajaran guru. Strategi model of teaching adalah suatu rancangan yang digunakan dalam proses belajar-mengajar, merancang materi pembelajaran, dan memandu pembelajaran di kelas demi tercapainya tujuan pembelajaran. Dengan adanya perbaikan-perbaikan dalam pembelajaran di siklus II ini diharapkan dapat meningkatkan kualitas pembelajaran menyimak cerpen dengan menggunakan media rekaman pembacaan cerpen diikuti pula dengan adanya perubahan perilaku siswa. Siswa diharapkan menjadi lebih aktif dan lebih antusias dalam mengikuti pembelajaran.

Pelaksanaan siklus II berlangsung selama tiga kali pertemuan $(6 \times 45$ menit). Pada pertemuan pertama guru menjelaskan teori tentang cerpen dan unsur intrinsik cerpen yaitu tema, tokoh dan penokohan, dan latar. Pada pertemuan pertama ini kondisi kelas lebih kondusif, sebagian besar siswa terlihat lebih tenang dan antusias dalam menyimak materi pembelajaran, bahkan ada beberapa siswa yang bertanya apabila ada penjelasan guru yang tidak dipahami. Pada kegiatan pembelajaran menjawab pertanyaan apersepsi didominasi oleh siswa yang menjawab pertanyaan guru, begitu pula pada kegiatan pembelajaran menyimak cerpen dengan menggunakan media rekaman pembacaan cerpen dan pada saat diskusi kelas didominasi oleh siswa yang aktif. Pada pertemuan pertama disiklus II ini, ada beberapa siswa yang tidak pernah berpartisipasi pada proses pembelajaran disiklus I, dan pada siklus II siswa tersebut telah memberikan partisipasinya pada proses pembelajaran. 
Menurut peneliti bertambahnya siswa yang aktif pada pertemun pertama disiklus II ini karena guru yang telah maksimal dalam memberikan motivasi kepada siswa, bentuk motivasi yang diberikan guru adalah berupa perhatian, apresiasi, dan dorongan untuk maju khususnya kepada siswa yang kurang dan tidak berperan aktif selama proses pembelajaran. Bentuk motivasi lain yang guru berikan berupa nilai, guru mengatakan kepada siswa "Bahwa siswa yang berperan aktif dalam proses pembelajaran ini akan mendapatkan nilai khusus atau tambahan". Selain itu salah satu upaya guru dalam membangkitkan motivasi siswa dalam belajar adalah guru yang mengajar sambil sesekali diselingi dengan humor supaya siswa tidak bosan selama proses pembelajaran. Guru juga telah maksimal dalam mengaitkan materi dengan realitas kehidupan, semua materi yang guru jelaskan dikaitkan dengan realitas kehidupan, sehingga sebagian besar siswa memahami materi pembelajaran dengan baik.

Pada pertemuan kedua guru menjelaskan unsur intrinsik cerpen yaitu alur, sudut pandang, gaya bahasa, dan amanat. Pada pertemuan kedua ini siswa semakin antusias dalam mengikuti proses pembelajaran, serta didominasi oleh siswa yang berperan aktif dan mengalami peningkatan dari pertemuan pertama. Pada pertemuan kedua ini guru memberikan motivasi berupa hadiah. Guru menyeleksi sepuluh siswa yang paling berperan aktif dan akan mendapatkan hadiah khusus dari guru. Oleh karena itu sebagian besar siswa berlomba-lomba berpartisipasi aktif dalam proses pembelajaran.

Pada pertemuan ketiga semakin menunjukkan hasil yang baik. hanya sebagian kecil siswa yang tidak bisa menjawab pertanyaan apersepsi, dan hanya satu siswa yang tidak sungguh-sungguh dalam menyimak cerpen dan mengerjakan tugas mengidentifikasi unsur-unsur intrinsik cerpen yang berupa tes objektif pilihan ganda karena siswa tersebut mengalami masalah dengan kesehatannya. Keantusiasan siswa dalam mengikuti proses pembelajaran tidak terlepas dari peran guru dalam membangkitan partisipasi siswa. Ini membuktikan bahwa proses pembelajaran terhadap siswa dan aktivitas guru pada siklus II mengalami peningkatan dari siklus I, sehingga tidak perlu dilanjutkan pada siklus berikutnya.

Hasil penilaian berdasarkan interval nilai yang ditetapkan menunjukkan bahwa pada siklus II 97,56\% atau 40 siswa dari target $65 \%$ siswa memperoleh nilai $\geq 65$, ini berarti terjadi peningkatan hasil belajar sebagai dampak dari peningkatan proses pembelajaran, sehingga peningkatan kualitas pembelajaran menyimak cerpen dengan menggunakan media rekaman pembacaan cerpen pada siswa kelas XI IPA2 SMA Negeri 1 Bontotiro kabupaten Bulukumba dinyatakan berhasil. 
Terjadinya peningkatan kualitas pembelajaran menyimak cerpen dengan menggunakan media rekaman pembacaan cerpen pada siswa kelas XI IPA2 SMA Negeri 1 Bontotiro Kab. Bulukumba, tidak terlepas dari penggunaan media rekaman yang diterapkan dalam pembelajaran menyimak cerpen, selain itu juga karena diterapkannya strategi baru pada RPP disiklus II. Strategi yang diterapkan adalah strategi model of teaching atau yang diartikan strategi model pengajaran guru, dengan penerapan strategi model of teaching pada RPP disiklus II, mampu meningkatkan keantusiasan dan gairah siswa dalam belajar.

Jika dibandingkan dengan hasil penelitian terdahulu yang pernah dilakukan oleh A. Suriani (2005) berupa penelitian eksperimen dengan judul penelitian "Penggunaan Tape Recorder dalam Pembelajaran Menyimak Siswa Kelas X Man 1 Makassar”, dan Andi Dewi Astuti (2008) berupa penelitian eksperimen dengan judul penelitian "Penggunaan Laborotorium Bahasa Dalam Pembelajaran Menyimak Cerpen Siswa Kelas X SMA Negeri 3 Sengkang", hasil penelitian ini sejalan dengan peneitian tersebut. Hasil penelitian Andi Dewi Astuti menunjukkan bahwa hasil pembelajaran menyimak cerpen dengan penggunaan laborotorium bahasa sudah cukup baik. Begitu pula dengan hasil penelitian yang dilakukan oleh A. Suriani menunjukkan hasil yang cukup baik.

Persamaan penelitian yang dilakukan oleh A. Suriani dan Andi Dewi Astuti dengan penelitian ini adalah dari segi aspek keterampilan berbahasa yang diteliti yakni menyimak dengan menggunakan media audio. Sedangkan perbedaannya adalah A. Suriani dan Andi Dewi Astuti mengunakan jenis penelitian eksperimen, sedangkan penelitian ini menggunakan jenis penelitian tindakan kelas.

Penelitian tindakan kelas yang pernah dilakukan oleh Fitriani (2010) dengan judul penelitian "Peningkatan Kemampuan Mengidentifikasi Unsur-Unsur Intrinsik Cerpen Melalui Media Rekaman Pembacaan Cerpen pada Siswa Kelas XI SMA Negeri 1 Tompobulu Kabupaten Maros", hasil penelitian ini sejalan dengan penelitian tersebut. Hasil penelitian Fitriani tersebut menunjukkan bahwa pembelajaran mengidentifikasi unsur-unsur intrinsik cerpen mengalami peningkatan yang signifikan yaitu siswa dapat berperan aktif selama proses pembelajaran sehingga kegiatan dalam proses belajar berlangsung dengan lancar seperti yang telah direncanakan. Hasil penelitian ini juga menunjukkan peningkatan yang signifikan dalam proses pembelajaran maupun dalam hasil pembelajaran. Suasana kelas tampak kondusif dan siswa tampak lebih antusias dan termotivasi mengikuti pembelajaran.

Persamaan penelitian yang dilakukan Fitriani dengan penelitian ini adalah dari segi jenis penelitian yang digunakan yakni penelitian tindakan 
kelas, aspek keterampilan berbahasa yakni menyimak, dan media yang digunakan. Sedangkan perbedaannya adalah dari segi strategi yang diterapkan dalam perencanaan pelaksanaan pembelajaran disiklus II. Strategi yang diterapkan Fitriani pada rancangan pelaksanaan pembelajarannya adalah inkuiri, dan strategi yang diterapkan dalam perencanaan pelaksanaan pembelajaran disiklus II dalam penelitian ini adalah model of teaching (Model pengajaran guru).

Adapun teori yang mendukung penelitian ini yaitu teori Tarigan mengemukakan bahwa pengalaman media audio dapat meningkatkan daya simak seseorang. ${ }^{7}$ Teori lain yang mendukung dalam penelitian ini adalah teori yang dikemukakan oleh Burhan Nurgiyantoro dalam Djumingin mengemukakan bahwa penggunaan media rekaman untuk pelaksanaan tes komprehensi dengar mempunyai beberapa keuntungan dan karenanya lebih disarankan. ${ }^{8}$ Beberapa keuntungan yang dimaksud antara lain; a). Menjamin tingginya tingkat keterpercayaan tes, b). Memungkinkan kita untuk membandingkan prestasi antara kelas yang satu dengan kelas yang lain walaupun selang waktu yang cukup lama, c). Jika tes memiliki tingkat kesahihan dan kepercayaan yang memadai, dapat digunakan berkali-kali, d). Dalam pengajaran bahasa asing dapat mengantikan penutur asli, e). Dapat merekam situasi-situasi tertentu pemakaian bahasa untuk dibawa ke kelas, dan karenanya bersifat pragmatik, e). Guru dapat mengontrol pelaksanaan tes dengan lebih baik, dan sebagainya.

\section{PENUTUP}

Berdasarkan hasil analisis dan pembahasan penelitian tindakan kelas ini, maka dapat disimpulkan hal-hal sebagai berikut. Pertama, pada tahap perencanaan guru dan peneliti telah berhasil menyusun rencana pelaksanaan pembelajaran yang lebih baik pada siklus II.

Kedua, pada tahap pelaksanaan proses pembelajaran pada siklus I kurang memuaskan dan suasana kelas kurang kondusif. Selain itu guru belum memaksimalkan usaha dalam memotivasi, memberikan penguatan terhadap siswa. Pada siklus II siswa menjadi lebih senang dalam menerima pelajaran bahkan sebagian besar siswa sudah berani mengemukakan pendapatnya dalam kegiatan diskusi dan dalam menjawab pertanyaan

${ }^{7}$ H.G. Tarigan, Menyimak Sebagai Suatu Keterampilan Berbahasa, (Bandung: Angkasa, 2008).

${ }^{8}$ Sulastriningsih Djumingin, Penialaian Pembelajaran Bahasa dan Sastra Indonesia Teori dan Penerapan. (Makassar: Badan Penerbit UNM, 2010), 193. 
apersepsi. Hal ini tidak terlepas dari peran guru dalam melaksanakan kegiatan pembelajaran dengan baik, khususnya saat guru menjelaskan materi pembelajaran dengan bahasa yang mudah dipahami dan selalu mengaitkan materi dengan realitas kehidupan. Selain itu guru juga sangat maksimal dalam pemberian motivasi kepada siswa. Adapun bentuk pemberian motivasi yang dilakukan guru yakni berupa pujian yang menyeluruh terhaap siswa dan motivasi dalam bentuk hadiah.

Ketiga, pada tahap evaluasi terjadi peningkatan kemampuan menyimak cerpen dengan menggunakan media rekaman pembacaan cerpen pada siswa kelas XI IPA2 SMA Negeri 1 Bontotiro Kabupaten Bulukumba setelah diadakan pembelajaran menyimak cerpen dengan menggunakan media rekaman pembacaan cerpen ketuntasan belajar pada siklus I yang mencapai ketuntasan belajar sebesar 56,09\% dengan nilai rata-rata 65,48. Hasil tersebut meningkat pada siklus II sebesar $97,56 \%$ dengan nilai ratarata 86,95 .

Setelah dilaksanakannya penelitian ini, maka peneliti memberikan saran sebagai berikut: a) Guru diharapkan dapat menggunakan media pembelajaran, khususnya penggunaan media rekaman pembacaan cerpen dalam pembelajaran menyimak cerpen; b) Bagi siswa diharapkan aktif mengikuti pembelajaran menyimak dan lebih giat melakukan latihan menyimak cerpen; c) Para praktisi atau peneliti dibidang pendidikan dan bahasa dapat menggunakan penelitian ini sebagai bahan rujukan untuk melakukan penelitian yang lain dengan strategis pembelajaran yang berbeda sehingga didapatkan berbagai alternatif strategi pembelajaran.

\section{DAFTAR PUSTAKA}

Astuti, Dewi. 2008. Penggunaan Laborotorium Bahasa dalam Pembelajaran Menyimak Cerpen Siswa Kela X SMA negeri 3 Sengkang. Skripsi. Makassar: FBS UNM.

Djumingin, sulastriningsih. 2010. Penialaian Pembelajaran Bahasa dan Sastra Indonesia Teori dan Penerapan. Makassar: Badan Penerbit UNM.

Fitriani. 2010. Peningkatan Kemampuan Mengidentifikasi Unsur-Unsur Intrinsik Cerpen Melalui media Rekaman Pembacaan Cerpen Pada Siswa Kelas XI SMA negeri 1 Tompubulu Kabupaten Maros. Skripsi. Makassar: FBS UNM. 
Oemarjati, Boen S. 1992. Dengan Sastra Mencerdaskan Siswa: Memperkaya Pengalaman dan Pengetahuan. Jakarta: Pustaka Sinar Harapan

Sudjana, Sudjana. \& Ahmad Rivai. (2013). Media Pengajaran. Bandung: Sinar Baru Algensindo.

Suriani, A. 2005. Penggunaan tape Recorder Dalam Pembelajaran Menyimak Siswa Kelas X Man 1 Makassar. Skripsi. Makassar: FBS UNM.

Tarigan, H.G. 2008. Menyimak Sebagai Suatu Keterampilan Berbahasa. Bandung: Angkasa.

Tarigan, H. G.(2013). Berbicara Sebagai Suatu keterampilan Berbahasa. Bandung: Angkasa. 